DOI: 10.1515/orga-2015-0003

\title{
Students' Perception of HR Competencies
}

\author{
Vesna Novak, Anja Žnidaršič, Polona Šprajc
}

\begin{abstract}
University of Maribor, Faculty of Organizational Sciences, Kidričeva cesta 55a, 4000 Kranj, Slovenia vesna.novak@fov.uni-mb.si, anja.znidarsic@fov.uni-mb.si, polona.sprajc@fov.uni-mb.si
\end{abstract}

\begin{abstract}
Background and purpose: Human resource professionalism receives considerable attention in terms of the competence of individual. In this article, we want to bridge the existing competencies of students and the perceived competencies that they assume will be developed and obtained during their studies. The purpose of our paper is a) to present competencies in general, b) to determine the meaning of the development of competencies in the field of higher education, and c) to present the role of competencies in human resource management. The aim of this paper is to examine the human resource competencies among students, and their judgments regarding the competencies they have already received during their studies.

Methodology: The questionnaire was distributed to full-time students of the Faculty of Organizational Science, University of Maribor, in such a way that both genders, both undergraduate and graduate studies, and all years of study were represented. We have measured students' opinions concerning their current and future perceptions about professional competencies in the HR field.

Results: Based on the self-assessment of fifteen HR competencies, we used hierarchical clustering performed with Ward's method and standardized variables and got two clusters. A t-test was used according to low or high levels of students' current competencies. The positive association between satisfaction with study programme and student's opinion on development of competencies during their studies was confirmed with one-tailed Pearson correlation coefficient.

Conclusion: The majority of students believe that they possess significant HR competencies. They have expressed a need for further education and training in that field. The students have assessed that the study programme allows them to acquire and develop the competencies for a successful task performance of the HR professional.
\end{abstract}

\section{Keywords: study, HR competencies, HR professional, development of students' HR competencies}

\section{Introduction}

Students nowadays are affected by different factors (economic, cultural, social etc.) depending on the time and place in which they live. Any study programme should enable students gaining competencies to use their knowledge, skills abilities, etc. to obtain suitable employment. Programmes within human resource management are no exception: they are preparing students to engage in human resource careers.

Competency is a complex concept that includes not only acquiring adequate knowledge, skills, and abilities, but maintaining these throughout one's career (Bradley, Drapeau and DeStefano, 2012). The role of HR has been elevated from clerical to administrative, administrative to managerial, managerial to executive, and executive to strategic partner (Venkata Ratnam and Srivastava, 1991; Budhwar, 2009). If the HR function is to fulfil its aims, HR professionals need to possess the competencies required to perform their responsibilities (Srimannarayana, 2013). Competencies for HR professionals may be defined by the view of senior managers and other employees or by an empirically tested conceptual framework (Ulrich, Brockbank, Yeung and Lake, 1995). They generally focus on the knowledge and abilities of HR professionals and the extent to which they can exploit HR knowledge to create business success (Ulrich, Brockbank, Johnson, Sandholtz and Younger, 2008).

The objective of our study is to present the perception of HR competencies of HR students and their willingness 
to develop the competencies that have been cited as valuable by researchers. We also studied the self-assessment of the presence of HR competencies, students' need for additional education and training for development HR competencies, their need to develop the competencies for the successful performance of the tasks of HR professionals, and the existence of differences among students. The goal of our study is also to determine the differences, if any, in the perception of HR competencies according to the year of study and satisfaction with study programme.

\subsection{Competencies in general}

Competence is a multidimensional construct characterized by the attainment, maintenance, and preservation of critical knowledge, skills and attitudes (Rubin et al., 2007). Boselie and Paauwe (2004, p. 554) define competence as the requirements for an individual to work, with an emphasis on the final result instead of attempts or contributions. Moore and Dainty (2002, p. 315) define competence as combination of ability and willingness to perform tasks. Most authors (Kröl, 2003, Kasiulis, 2005, Diskienė and Marčinskas, 2007 and others) claim that performance of working duties currently requires a combination of qualifications, knowledge, approaches, motives, values, abilities and other constituents of competences.

Via the setting of a systemic, dynamic, cognitive and holistic framework for building management theory, the competence perspective has integrated and extended some fundamental ideas developed over the last several decades under various banners, including 'resource base', 'dynamic capabilities' and 'core competences perspectives' (Sanchez, 2004, p. 521). Barney (1991, p. 111) claimed that the final requirement for a firm's resource to be a sustained competitive advantage is that there must be no strategically equivalent valuable resources that are themselves either not rare or imitable.

Nelson and Winter (1982) proposed that business success is found in organizational routines, which are the common activities a firm develops in its use of specific resources. Rumelt (1994) proposed that competencies become widespread across products or businesses, by changing more slowly than the products they make possible, by embodying 'collective learning' in the firm, and by embracing competition to acquire the best skills and capabilities.

A professional competence combines the knowledge and skills that are related to the employee's particular field of work; it also encompasses all the characteristics, abilities, and experience employed in the everyday activity as specialized knowledge; social competence is the ability to communicate with other people in a group; personal competence is the ability to learn, analyse and develop personal characteristics, and learn from personal experience, as well as cognitive abilities, analysis, and the ability to find solutions in critical situations; managerial competence is the ability to inspire, motivate, control stress and conflicts, and the ability to be in charge of the work of others; methodical competence is the ability to organize one's work, plan, adapt and prioritize (Druteikiene, Česyniene and Stankevičiene, 2013).

\subsection{Competencies in human resource management}

Since the 1980s, the shift from 'personnel management' to 'human resource management' has required treating people as a key resource (Armstrong, 2009). Armstrong claimed that human resource management puts greater emphasis on business functions, rather than problem-solving and mediation. The most popular version of human resource management roles can be attributed to Ulrich (1997), and it has been understood that it is necessary for HR professionals that they assume certain roles if they are about to make a contribution to the business. However, managing human resources during organizational change is not an easy task. HR professionals are supposed to have a crucial role in managing change in an organization.

Their roles must be related to the organizational needs. With the increase in general competition, organizations must become more adaptable, resilient, agile and customer-focused in order to succeed (Ullah, 2012). The roles of HR professionals are not only important for managing organizational change but also for establishing changes in a business area. (Ullah, 2012). Globalization and information technology have been important for the HR professionals and their work (Brockbank, 1997, Bawa and Ali, 1999 and Caldwell, 2003).

As one of the pioneers in researching the emerging impact of workplace change on personnel practice, Storey (1992) proposed four personnel roles: advisors, handmaidens, regulators, and change makers. Abigail, Findley, Hine, Thompson and McKinlay (1997) considered the handmaidens' role to be a companion role. Regulators are responsible for rules and business strategy. Change makers' role as personnel managers is to face the marketing area and make strategic moves through soft HR interventions in order to enhance employee motivation and commitment. HR professionals retain a key role in providing expertise and advice, and in ensuring that managers follow disciplinary procedures and thus avoid possible damaging situations (Harris, Doughty and Kirk, 2002). The professional HR perspective is the best example of consistency, rule compliance and statutory management (Gilmore and Williams, 2007).

Competencies for HR professionals may be defined from different aspects by using an empirically tested base (Ulrich et al., 1995). Chanda and Kabra (2000) stated that the competency of HR professionals is a part of knowledge, skills, attitudes, and values. Ulrich et al. (1995) de- 
fined competency in conjunction with business, but more likely as the competitive advantages of business. Their HR model combines different views of competencies, which are divided into four domains: knowledge of the business, personal credibility, HR expertise and management of change. They argue that the management of change is critical, as an organization's external rate of change must be matched by an internal rate of change if the organization is to remain competitive.

The second most important element, personal credibility, deals with the extent to which HR professionals embody the values of the firm and act with proper attitudes when dealing with HR issues in their efforts to create results (Ulrich and Eichinger, 1998 in Long and Ismail, 2010). HR professionals, by virtue of their knowledge of human performance, are well positioned to exercise strategic leadership and contribute significantly to a firm's competitive advantage (Long and Ismail, 2011, p. 1054). In high-performing companies, HR professionals are a part of business at a strategic level. They may manage the culture, change, communication, decision making and connectivity (Boselie and Paauwe, 2004). Graham and Tarbell (2006) represented the employee's view regarding the credibility of HR professionals. Based on the study conducted on European companies, Boselie and Paauwe (2004) suggested that personal credibility and the HR function have a positive effect on the importance of HR function and its professionals.

\subsection{Higher education and development of competencies}

As previously mentioned, competences integrate knowledge, skills, attitudes, and values. At the same time, the meaning of competence-based education should be explored; this is a major point of interest in this paper. Competence-based higher education is a type of study that focuses on the competences that are achieved and assessed during the study programme (Lambrechts, Mula, Ceulemans, Molderez and Gaeremynck, 2012). Competence-based higher education enables students to obtain the relevant knowledge, skills, values and attitudes that they will require in their future professional and personal lives (Lambrechts et al., 2012, p. 67).

Rychen (2002) claims that the use of competences contributes to an improved process of assessing students, regarding the abilities they acquire to face study challenges, but also to setting the important educational goals that improve education systems and lifelong education. For measuring the views of students on current and future professional competences in the field of HR, a list of competencies of Slovenian managers of human resources was used (Kohont, 2005, p. 209).

Kohont (2005, p. 117) identified fifteen competences within the HR professional field: leadership, strategic thinking, teamwork, communication, change management, decision-making and responsibility, creativity and innovation, professionalism, people-orientation, results-orientation, business knowledge, time and work organization, accuracy, analytical thinking, and the use of ICT.

Current research provides very little empirical evidence regarding the influence of academic higher education on the development of professionalism among students (Zlatkin-Troitschanskaia, Förster and Kuhn in Blőmeke, Zlatkin-Troitschanskaia, Kuhn and Fege, 2013, p. 159). The research is based on Klieme and Leutner's (2006) definition of competence as a context-specific performance disposition. This definition means that subject-specific knowledge and thinking are essential with regards to conceptualizing competence in the study area. In contrast to personality traits, competencies associated with particular behaviours are learnable (Bird, 1995).

This challenges educators to develop study opportunities (Bjornali and Støren, 2012). Taconis, Van der Plas and Van der Sanden (2004) and Baartman, Bastiaens, Kirschner and Van der Vleuten, (2007) emphasized that competence-based curricula should address knowledge, skills, self-esteem and attitudes in a connected way, since each of these separately is not sufficient for the desired competent professional behaviour.

The goal of this paper is to investigate the presence of HR competencies among students of the HRM study programme and their attitudes toward additional education and training for development of those competencies. In addition, the differences in development of HR competencies among students with different levels of study satisfaction and the differences in their estimation of the extent to which the study programme enables the acquisition and the development of the competencies necessary for the successful performance of tasks of HR professional are examined. Based on the goal of the paper a research question (RQ) and three research hypotheses $(\mathrm{RH})$ were stated.

RQ1: How many groups of students exist based on their self-assessment of presence of fifteen HRM competencies?

RH1: Groups of students with higher levels of HR competencies (obtained from results of $R Q 1$ ) have on average greater needs for additional education and training for development of those competencies than students with lower self-assessment of present competencies do.

RH2: A positive correlation exists between satisfaction with each student's study programme and their opinion that their study programme enables them to acquire and to develop the competencies necessary for the successful performance of tasks of HR professional. 
RH3: The opinion that the study programme enables the acquisition and the development of the competencies necessary for the successful performance of tasks of HR professional exists and differs among students of according to their year of study.

\section{Methods}

\subsection{Instrumentation}

The socio-demographic part of the questionnaire include questions on gender, the type of the study, and the year of the study. Students were asked to self-assess the current presence of each of the fifteen different competencies (presented in Table 2), and later to evaluate the need for additional education and training on those competencies and the extent of competencies development during the current study programme. All variables on competencies were measured on the 5-point Likert type scale of presence, in which ' 1 ' means 'not present at all', and ' 5 ' means 'completely present'. Students were asked to estimate their satisfaction with the study programme and the extent to which the study programme enables the acquisition and the development of the competencies necessary for the successful performance of tasks of HR professional.

\subsection{Population, sample and data collec- tion method}

The survey was performed in spring 2009 among students of Human Resources and Educational Systems of Faculty of Organizational Sciences, University of Maribor. The questionnaire was delivered in paper format to a non-probabilistic convenience sample of students who attended lectures. A total of 155 questionnaires were completed.

\subsection{Data analysis}

Data gathered from the survey were first analysed with hierarchical clustering in order to determine different groups of students according to their opinion of the presence of fifteen HR competencies. In the second step, the significant differences of student needs for additional education and training for development of HR competencies were examined between two obtained groups of students according to their level of present HR competencies. Later, the correlation between each students' satisfaction with their study programme and their opinion that their study programme enables them to acquire and to develop the competencies necessary for the successful performance of tasks of HR professional was examined. The differences in the students' opinion that the study programme enables them the acquisition and the development of the competencies necessary for the successful performance of tasks of HR professional were investigated with analysis of variance and robust test of equality of means.

\section{Results}

\subsection{Sample description and descriptive statistics of the questionnaire items}

The sample consists of 155 students; $78.7 \%$ were female and $21.3 \%$ were males; $54.8 \%$ of respondents were studying in the professional higher degree programme and $45.2 \%$ in the academic higher degree programme. The highest proportion of the respondents was enrolled in the second year of the study (40.6\%), a third (33.6\%) was in the first year and one quarter $(25.8 \%)$ in the third year of the study. Almost all respondents $(94.8 \%)$ had already deliberated their own competencies.

Table 1 presents descriptive statistics for fifteen HR competencies in two different contents: self-assessment of the current presence of the competency and the need for additional education and training for the development of the competency. Students on average assessed their people-orientation competency the highest $(\overline{\mathrm{x}}=4.27)$, followed by creativity and innovation $(\overline{\mathrm{x}}=4.14)$, their communication skills $(\overline{\mathrm{x}}=4.02)$, and accuracy $(\overline{\mathrm{x}}=4.01)$. The lowest estimated competency was their strategic thinking $(\overline{\mathrm{x}}=2.98)$. On average, students have the highest need for education and training for development of creativity and innovation $(\overline{\mathrm{x}}=3.67)$ and team work $(\overline{\mathrm{x}}=3.63)$, while the lowest need was expressed for analytical thinking $(\overline{\mathrm{x}}=$ $3.10)$ and business knowledge $(\overline{\mathrm{x}}=3.03)$.

\subsection{Hierarchical clustering}

In order to answer to the first research question, hierarchical clustering is based on the self-assessment of fifteen HR competencies. The clustering was performed with Ward's method and standardized variables. The dendrogram (Figure 1) clearly shows that two clusters of students exist, based on their self-assessment of current competencies.

The larger group of students consists of 113 students $(72.9 \%)$ and the cross table reveals that $74.1 \%$ of students have already thought about their competencies belonging to that group. In addition, we have attempted to determine what the average assessments of present competencies were in both groups.

Figure 2 presents both groups of students obtained from hierarchical clustering and their average estimates of self-assessment of their present competencies. Both groups differ significantly at the $5 \%$ significance level in their average estimates for all competencies, except in the assessment of accuracy and analytical thinking (detailed result of t-tests are not presented here). Therefore, the group with higher average values was called 'Students with higher self-assessment of their present competencies' (consisting of 113 respondents; drawn with solid grey line in Figure 2) and the other group was 'Students with lower self-assessment of their present competencies' (consisting of 42 respondents; drawn with black dashed line in Figure 2). 
Table 1: Descriptive statistics for the self-assessment of the current presence of the competency and the need for additional education and training for the development of the competency

\begin{tabular}{|l|c|c|c|c|}
\hline \multirow{2}{*}{ Competency } & \multicolumn{2}{|c|}{$\begin{array}{c}\text { Self-assessment of the } \\
\text { current presence }\end{array}$} & \multicolumn{2}{c|}{ Need for additional education and } \\
& Mean & SD & Mean & SD \\
\cline { 2 - 5 } & 3.52 & 0.840 & 3.47 & 0.900 \\
\hline Leadership & 2.98 & 0.943 & 3.46 & 0.885 \\
\cline { 4 - 5 } Strategic thinking & 3.23 & 1.068 & 3.63 & 1.038 \\
Teamwork & 4.02 & 0.886 & 3.41 & 0.888 \\
Communication & 3.30 & 0.869 & 3.27 & 1.008 \\
Change management & 3.73 & 1.065 & 3.55 & 1.046 \\
Decision-making and responsibility & 4.14 & 0.846 & 3.67 & 0.968 \\
Creativity and innovation & 3.29 & 0.806 & 3.60 & 1.114 \\
Professionalism & 4.27 & 0.724 & 3.55 & 1.135 \\
People-orientation & 3.80 & 0.886 & 3.29 & 0.933 \\
Results-orientation & 3.30 & 1.002 & 3.03 & 1.006 \\
Business knowledge & 3.66 & 0.824 & 3.43 & 1.069 \\
Time and work organization & 4.01 & 0.806 & 3.25 & 1.142 \\
Accuracy & 3.30 & 0.907 & 3.10 & 1.172 \\
\cline { 3 - 5 } Analytical thinking & 3.76 & 0.919 & 3.56 & 1.082 \\
Use of ICT & & & \\
\hline
\end{tabular}

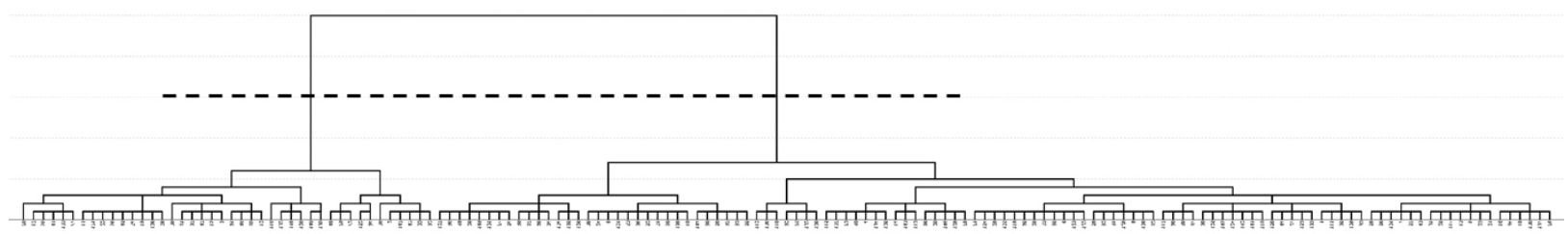

Figure 1: Dendrogram from hierarchical clustering

\subsection{T-tests}

In the following section, the results of three groups of t-tests are presented. First, we attempt to determine the answer to the first research hypothesis regarding whether groups of students with higher levels of their HR competencies have on average a greater need for additional education and training for development of those competencies than a group of students with lower self-assessment of present competencies. The results of the t-tests are presented in Table 2, while average values are depicted in Figure 3.

The group of students with higher self-assessment of present competencies has, on average, a statistically significantly greater need for additional education and training for the development of the individual competencies in nine out of fifteen HR competencies at a 5\% significance level. Those competencies are: Leadership $(\mathrm{t}=1.984, \mathrm{p}=0.025)$, Strategic thinking $(\mathrm{t}=1.960, \mathrm{p}=0.026)$, Teamwork $(\mathrm{t}=2.765, \mathrm{p}=0.003)$, Communication $\quad(\mathrm{t}=2.284, \mathrm{p}=0.012)$, Change management $(\mathrm{t}=2.436, \mathrm{p}=0.008)$, Decision-making and responsibility $(\mathrm{t}=2.833, \mathrm{p}=0.003)$, Results-orientation $\quad(t=2.399, \mathrm{p}=0.009), \quad$ Business knowledge $(\mathrm{t}=1.825, \mathrm{p}=0.035)$, and Accuracy $(\mathrm{t}=2.461, \mathrm{p}=0.007)$. Based on the above results, the first research hypothesis can be confirmed since students with higher levels of present competencies have expressed greater needs for additional development for nine out of fifteen competencies. 


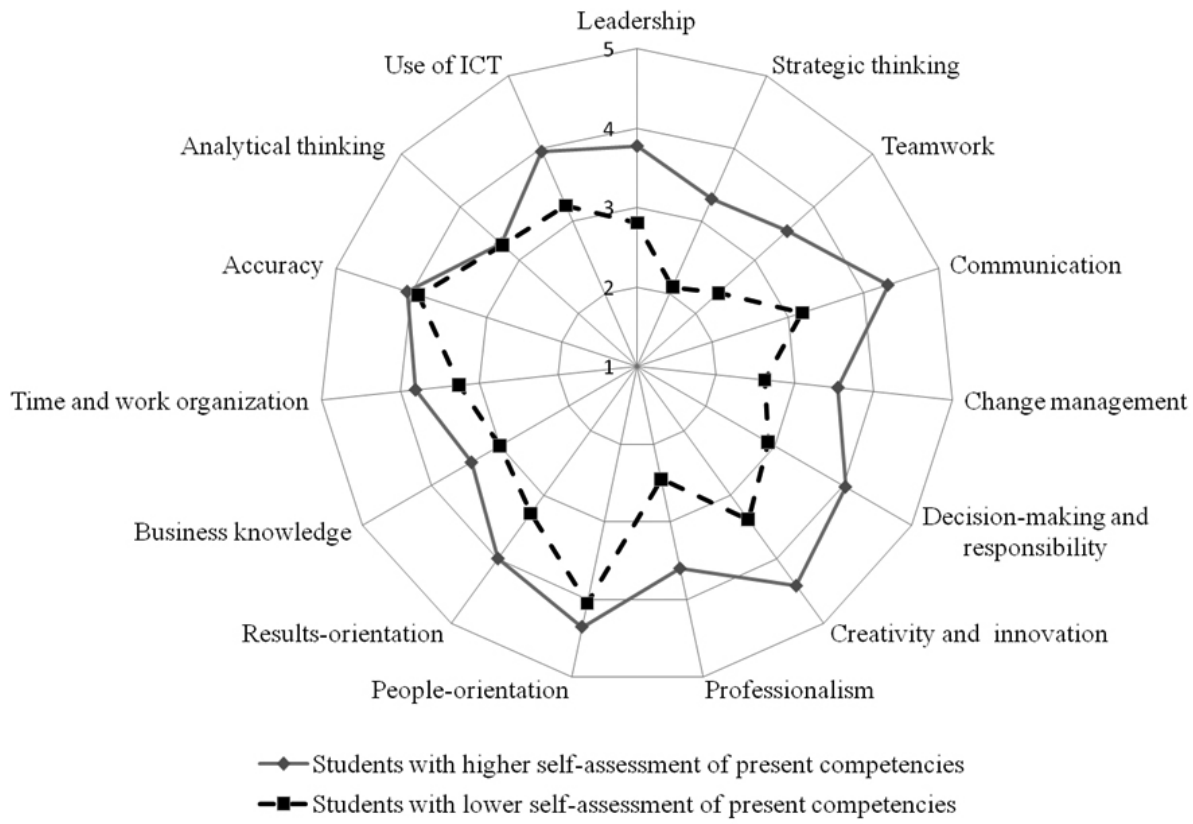

Figure 2: Two groups of students from hierarchical clustering and their average estimates of self-assessment of their present competencies

Table 2: Results of the t-test for the students'need for additional education and training for development of HR competencies according to low or high level of the present competencies

\begin{tabular}{|c|c|c|c|c|c|c|c|c|}
\hline & \multicolumn{2}{|l|}{ Average } & \multicolumn{2}{|c|}{$\begin{array}{l}\text { Levene's Test of } \\
\text { Equality of Variances }\end{array}$} & \multicolumn{3}{|c|}{ T-test of Equality of Means } & \multirow[b]{2}{*}{$\mathrm{p} / 2$} \\
\hline & Higher ${ }^{\mathrm{a}}$ & Lower $^{\mathrm{a}}$ & $\mathbf{F}$ & Sig. & $\mathbf{t}$ & df & p (2-tailed) & \\
\hline Leadership & 3.56 & 3.24 & 5.751 & 0.018 & 1.984 & 153 & 0.049 & 0.025 \\
\hline Strategic thinking & 3.55 & 3.24 & 0.088 & 0.768 & 1.960 & 153 & 0.052 & 0.026 \\
\hline Teamwork & 3.77 & 3.26 & 0.861 & 0.355 & 2.765 & 153 & 0.006 & 0.003 \\
\hline Communication & 3.50 & 3.14 & 0.669 & 0.415 & 2.284 & 153 & 0.024 & 0.012 \\
\hline Change management & 3.39 & 2.95 & 0.285 & 0.594 & 2.436 & 153 & 0.016 & 0.008 \\
\hline $\begin{array}{l}\text { Decision-making } \\
\text { and responsibility }\end{array}$ & 3.69 & 3.17 & 0.003 & 0.957 & 2.833 & 153 & 0.005 & 0.003 \\
\hline $\begin{array}{l}\text { Creativity and inno- } \\
\text { vation }\end{array}$ & 3.73 & 3.50 & 0.339 & 0.561 & 1.344 & 153 & 0.181 & 0.090 \\
\hline Professionalism & 3.65 & 3.45 & 0.315 & 0.576 & 1.006 & 153 & 0.316 & 0.158 \\
\hline People-orientation & 3.58 & 3.50 & 0.225 & 0.636 & 0.366 & 153 & 0.715 & 0.358 \\
\hline Results-orientation & 3.40 & 3.00 & 0.102 & 0.750 & 2.399 & 153 & 0.018 & 0.009 \\
\hline Business knowledge & 3.12 & 2.79 & 0.539 & 0.464 & 1.825 & 153 & 0.070 & 0.035 \\
\hline $\begin{array}{l}\text { Time and work } \\
\text { organization }\end{array}$ & 3.45 & 3.38 & 3.697 & 0.056 & 0.363 & 153 & 0.717 & 0.358 \\
\hline Accuracy & 3.38 & 2.88 & 1.291 & 0.258 & 2.461 & 153 & 0.015 & 0.007 \\
\hline Analytical thinking & 3.12 & 3.05 & 0.095 & 0.758 & 0.317 & 153 & 0.751 & 0.376 \\
\hline Use of ICT & 3.55 & 3.60 & 0.328 & 0.568 & -0.237 & 153 & 0.813 & 0.406 \\
\hline
\end{tabular}




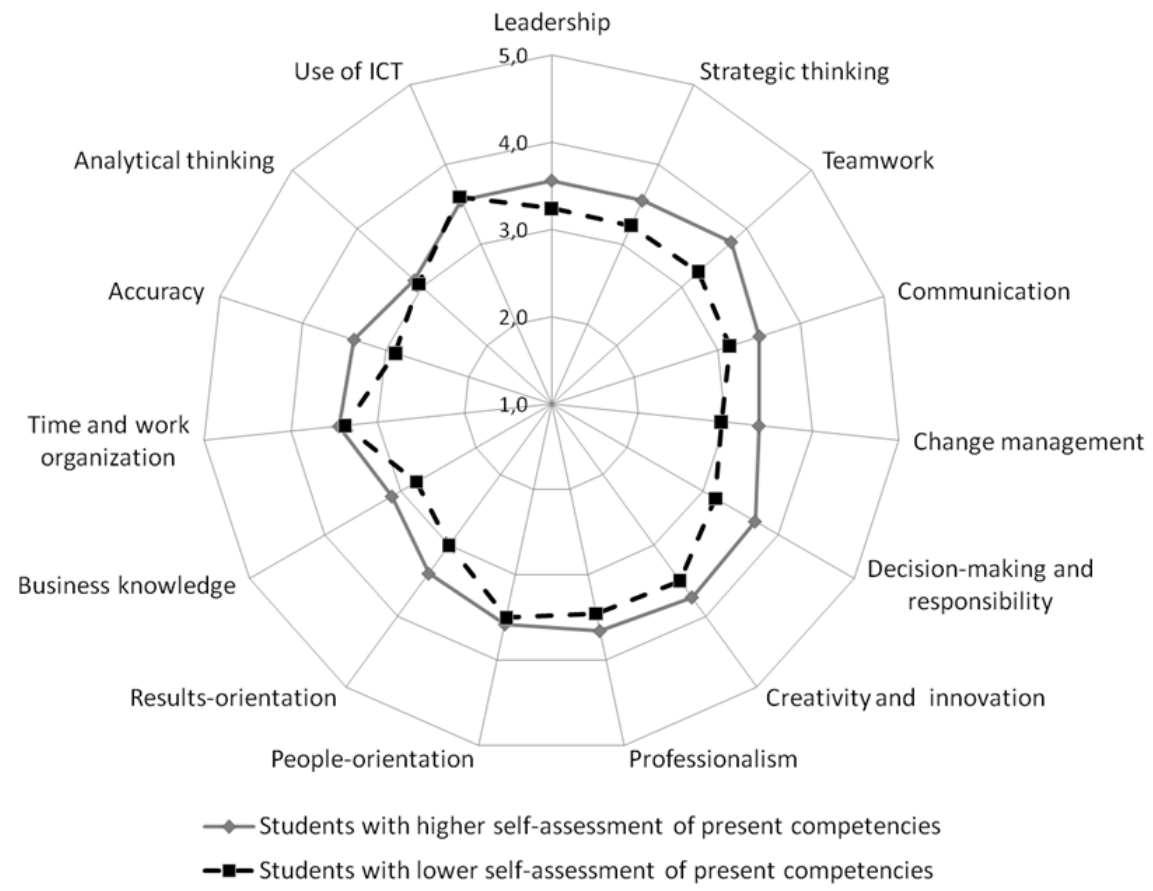

Figure 3: Average estimates of students' need for additional education and training for development of HR competencies according to low or high level of the present competencies

Table 3: Results of the ANOVA for the student'opinion that study programme enables the acquisition and the development of the competencies necessary for the successful performance of tasks of HR professional according to year of the study

\begin{tabular}{|c|c|c|c|c|c|c|c|c|c|c|c|}
\hline \multirow{2}{*}{$\begin{array}{c}\text { Year of the } \\
\text { Study }\end{array}$} & \multicolumn{3}{|c|}{ Descriptive statistics } & \multicolumn{4}{|c|}{ Test of Homogeneity of Variances } & \multicolumn{4}{|c|}{ Robust Tests of Equality of Means } \\
\hline & $\mathrm{N}$ & Mean & SD & $\begin{array}{l}\text { Levene } \\
\text { Statistic }\end{array}$ & df1 & $\mathrm{df} 2$ & $\mathrm{p}$ & $\begin{array}{l}\text { Brown-For- } \\
\text { sythe Sta- } \\
\text { tistic }\end{array}$ & df1 & $\mathrm{df} 2$ & $\mathrm{p}$ \\
\hline 1st year & 52 & 3.71 & 1.091 & \multirow{3}{*}{4.339} & \multirow{3}{*}{2} & \multirow{3}{*}{152} & \multirow{3}{*}{0.015} & \multirow{3}{*}{8.532} & \multirow{3}{*}{2} & \multirow{3}{*}{132.4} & \multirow{3}{*}{0.000} \\
\hline 2nd year & 63 & 4.32 & 0.820 & & & & & & & & \\
\hline 3rd year & 40 & 4.35 & 0.700 & & & & & & & & \\
\hline
\end{tabular}

\subsection{Correlation}

The association between satisfaction with study programme and students' opinion that the study programme enables them to acquire and to develop the competencies necessary for the successful performance of tasks of HR professional was examined with a one-tailed Pearson correlation coefficient. The p-value of the Pearson correlation coefficient was equal to 0.001 , indicating that both variables are statistically significantly correlated at the $1 \%$ significance level. The value of the Pearson correlation coefficient was equal to 0.250 , which means that the second research hypothesis could be confirmed. Therefore, a low positive linear relationship between students' satisfac- tion with their study programme and their opinion that the study programme enables them to acquire and to develop the competencies necessary for the successful performance of tasks of HR professional exists.

\section{ANOVA}

The third research hypothesis was analysed with ANOVA. The results in Table 3 shows that the average student's opinion that study programme enables them to acquire and to develop the competencies necessary for the successful performance of tasks of an HR professional of the 1st year students is equal to 3.71 on a 5-point scale: the average 
opinion of 2 nd year students is equal to 4.32 , and the average opinion of $3 \mathrm{rd}$ year students is equal to 4.35. Since the p-value of Levene's test of equality of variances was equal to 0.015 , the assumption of equal variances across groups could not be confirmed at a 5\% significance level, the robust test of equality of means has to be performed instead of ANOVA.

The p-value of the Brown-Forsythe Statistic from the robust test was equal to 0.000 ; therefore, we can conclude that statistically significant differences exist, at a 5\% significance level, among students of different years of study in the average student's opinion that the study programme enables the acquisition and the development of the competencies necessary for the successful performance of tasks of HR professional.

In addition, multiple comparisons with a Games-Howell's test were preformed, and we determined that statistically significant differences exist at 5\% significance level between first and second $(p=0.004)$ and first and third year students $(p=0.003)$ in their opinion that their study programme enables the acquisition and the development of the competencies necessary for the successful performance of the tasks of HR professional. Therefore, the third research hypothesis is confirmed.

\section{Discussion}

The research concerning acquiring and developing the competencies that an HR professional needs for his or her successful work performance and results of the empirical research represent the basis allowing us to discuss the findings in in two parts.

\section{Student self-assessment of developed competencies and need to acquire and develop the HR professional com- petencies}

For students, the recognition of the proper competencies is of the utmost importance, because in this way they can manage the further development of all competencies, both of those which are well developed as well as those that are inadequately developed yet necessary for the profession that students intend to practice. University education has, to a certain degree, influence upon the competency development (Pavlin, 2012, p.125); however, it is important that each student can further acquire and develop them by means of additional training and education.

The research has indicated that the students have high estimations regarding current HR competencies, because there is not a single competency self-assessment for which it could be assured that it is expressed to a lesser degree or not at all. On the basis of the self-assessment of the current HR competencies, we have divided the students into two distinctive groups; the group of students with higher self-assessment of HR competencies and the group of students with lower self-assessment of HR competencies.
This result could be interpreted according to Brečko's assertion (2006, p.245) that individuals differ among themselves regarding whether the abilities, values and motives prevail in their self-image or not. A similar opinion is shared by Funčič Masič, Bakračevič Vukman and Schmidt (2011, p.93), who stated that to an individual's endeavours, motivation, perseverance and flexibility are influenced to the degree that he/she trusts his abilities to control proper functioning and that of the environment.

People-orientation and communication are ranked by Kohont (2005, p.118) among the most important competencies of the HR professional. It is good to see that the students (according to their current self-estimated presence of the competencies) have given the highest appraisal precisely to people-orientation $(=4.27)$, creativity and innovation $(=4.14)$, and communication $(=4.02)$. People-orientation is important for HR professionals because they deal mostly with people at work (Kohont, 2005, p.111). Consequently, it is important that they be ready and open for cooperation. Ulrich et al. $(2008$, p.19) stated that HR professionals should be able to establish an innovation protocol that helps shape new ideas, and they also should be able to instil a spirit of innovation among all employees. Communication skills in HR professionals are reflected in their ability to convey a sensible oral and written message as well as in their active listening of the others in case of interpersonal communication. Moreover, the research of the Society for Human Resource Management (SHRM, 2010, p.6) cites communication as the most important competency of the senior HR leaders in the United States.

The participants of the research attributed the lowest average evaluation of their current HR competencies to strategic thinking ( $=2.98$ ); however, this does not necessarily mean that this competency is not present among them, because on average they have evaluated it as medium present. Recently, strategic thinking is becoming increasingly important due to the transformation of the HR function from administrative into strategic one (Budhvar, 2009). HR professionals should be able to establish a process to ensure strategic clarity and be able to align organizational action to make the strategy happen (Ulrich et al., 2008, p.10). Consequently, an HR professional should have a broad perspective about organization while simultaneously understanding how decision making and functioning are interwoven at different levels of business activity. The research of the Society for Human Resource Management (SHRM, 2010, p.6) ranks the competency 'strategic thinking' in Canada, India and in the Middle Eastern and in the Northern African countries at first place, while in the United States it is at second place.

The growing importance of the strategic thinking due to globalization with respect to the process of internationalization is also indicated by the statement that this competency is ranked by HR managers in the first place in Slovenian multinational companies (Kohont, 2014, p.304). 
Furthermore, we also think that it is encouraging that the participants in the study feel, in regards to almost all HR competencies, at least a medium need for additional education and training. O'Donoghue and Maguire (2005, p. 442) stated that each individual should assume responsibility for his/her own development and employability and consider his/her career in the sense of a broader employability. Thus, we can infer that the students are aware of the importance of competency development in a broader context because additional education and training are part of their career development.

The students have given the highest average appraisal to the need to educate and train themselves with regards to creativity and innovation $(=3.67)$, and teamwork $(=$ 3.63). Nowadays, it is important for an HR professional to develop creativity and innovation skills, particularly on account of the ability to adjust to constant changes, to restructure and to transmit innovations into his HR activity as well as because of their indirect influence on the company's performance.

Finally, the development of the competency for a teamwork helps an HR professional to develop the ability to form the working teams focused on achieving the goals, and his capacity to choose the competent members.

The aforementioned results are encouraging because they indicate that the students are also aware of the importance of competency development from the point of view of a better employability, because the team-work is precisely the competence mentioned by Akkuyunlu, Kovačič, Pavlin and Svetlik (2009, p.69) as a key factor for healthy functioning in the workplace and society.

Taking into consideration the fact that changing working conditions and labour markets are causing shifts in relation to the social competencies and transferable skills of the graduates (Uhomoibhi, 2009, p.250), we believe that the students could consolidate those competences considered by employers to be particularly important by means of additional training in the workshops.

\section{HR competencies development in the course of study}

In discussing HR competencies, we first have to mention the individuals who choose the profession of HR professional and thus take responsibilities for decisions about their professional and career paths (Devjak, Devjak and Polak, 2014, p.4). In this manner, they realize their aspirations and ambitions in the faculties that represent the basis for the development of a creative and knowledge-based society, because their primary mission is to educate high-level experts who will take care of sustainable development.

As the third participant in this relationship, organizations must be mentioned. Adamska and Minárová (2014, p.69) are of the opinion that knowledge creation, development, application and evaluation are of key importance for ensuring the further development of the organization as well as for acquiring and maintaining competitive ad- vantage.

HR competencies are essential for the successful performance of HR professionals. It is a generally accepted fact that suitably educated and trained people can respond appropriately to expected changes in the business (Garavan and McGuire, 2001). This is why we have to know which competencies should be presented to them. In accordance with the abovementioned, HR professionals should, in the course of the study, acquire a suitable education and develop the necessary HR competencies. The results of our research have demonstrated that the participants mainly agree that the study programme allows them to acquire and develop the competencies for the successful performance of the duties pertaining to an HR professional during their courses of study $(=4.12)$.

This is in accordance with the thinking of Way (2002: 484), who stated that the study programme should allow to HR students to acquire the necessary competencies, because this is the only way they can effectively carry out the work of HR professionals. A similar view is also shared by Johnson and King (2002), but they emphasize that education should change in accordance with the expected business changes, this also means the curricula should be appropriately adjusted.

We would only add that in doing so all participants have to be taken into consideration: in the first place, university institutions, employers and students, as well as external factors (e.g. situation on the labour market). This is why we agree with the recommendation of Pavlin (2012, p.127) that university institutions should systematically establish relationships with employers, with the purpose of informing them about the expectations of programs and graduates, and the intention to design study programs together with them.

Furthermore, we have established that statistically significant differences exist among the students of different years in their opinion regarding the study programme allows them to acquire and develop the competencies for a successful task performance as an HR professional during their course of the study. As students advance to higher years of study their opinion scores increases. We expected such a result and explain it by the fact that the students of the last year of studies have been acquainted during the lectures with the programme in its entirety, while the students of the first year have been acquainted only with the theoretical part of the program.

The majority of the participants of the research expressed their satisfaction with the study programme ( = 3.80). Furthermore, we have established that the students who are more satisfied with the study program have more positive opinions regarding whether the study programme allows them to acquire and develop the competencies for a successful task performance of the HR professional during the course of the study. Having in mind the fact that many authors (Kotler, Keller, Brady, Goodman, and Hansen, 
2012; Lovelock and Wirtz, 2011) interpret satisfaction as a positive feeling, i.e. fulfilment felt by an individual in using a service or a product, we can infer that the students had been, at the time of their enrolment in university, well acquainted with the study program, its contents, and performance. If we look at the students as service users, we can conclude that the study programme has, to a large extent, fulfilled or even exceeded their expectations.

Students' self-assessment of HR competencies has indicated that they have them, at least to a medium degree and the majority of them even to a higher degree. The students are aware of the importance of developing such competencies: most of them have even expressed the need for further education and training, in addition to their studies related in the same field. Their satisfaction with the study programme is expressed to a higher degree; the students assert that the study programme allows them to acquire and develop the competencies for a successful task performance of the HR professional. We believe that the graduates with developed HR competencies will achieve better results, in the working environment as well as in the process of further education and life in general. They will be more self-confident and convinced that the work they are carrying out is appropriate for them. This can give them advantages in society and the labour market, above all because of their personal motivation and positive orientation toward the future.

In the next stage of the research, the study would be designed as a longitudinal survey in which students will be asked to assess the presence of HRM competencies during their studies, at graduation and few years after graduation. We propose that the faculty consistently pursue students' competencies and extend the research to those graduates already involved in the working environment, carrying out the tasks of HR professionals. We have limited our research to the students' competency self-assessment, so we propose that the faculty also perform other evaluations of the present HR competencies. We believe that in this way the faculty could more easily and better adjust the curricula of the study programs to suit the needs of the HR competencies development.

\section{Literature}

Adamska, M. \& Minárová, M. (2014). Role of Learning Organization in Building Consumer Confidence. Ekonomie a Management, 17(1), 62-72, http://dx.doi. org/10.15240/tul/001/2014-1-005

Abigail, M., Findley, P., Hine, J., Thompson, P. \& McKinlay, A. (1997). Handmaid's tale or midwives of change? Strategic Change. 6(8), 469-480, http://dx.doi. org/10.1002/(SICI)1099-1697(199712)6:8<469::AIDJSC343>3.0.CO;2-O

Akkuyunlu, A., Kovačič, H., Pavlin, S. \& Svetlik, I. (2009). Report on the Qualitative Analysis of Higher
Education Institutions and Employers in Five Countries: Development of Competencies in the World of Work and Education. Ljubljana: University of Ljubljana, Faculty of Social Sciences. Retrieved October 20, 2014, from http://www.decowe.org/static/uploaded/htmlarea/finalreportshegesco/Qualitative_Analysis_of_ HEIs_and_Employers_in_Five_Countries.pdf

Armstrong, M. (2009). Armstrong's Handbook of Human Resource Management Practice. London; Philadelphia: Kogan Page.

Baartman, L.K.J., Bastiaens, T.J., Kirschner, P.A. \& Vleuten van der, C.P.M. (2007). Evaluation assessment quality in competence-based education: a qualitative comparison of two frameworks. Educational Research Review, 2, 114-129, http://dx.doi.org/10.1016/j.edurev.2007.06.001

Barney, J.B. (1986). Strategic factor markets: expectations, luck and business strategy. Manage Sci, 32, 12341241, http://dx.doi.org/10.1287/mnsc.32.10.1231

Barney, J.B. (1991). Firm resources and sustained competitive advantage. J Manage, 17, 99-120, http://dx.doi. org/10.1177/014920639101700108

Bawa, M.A. \& Ali, J. (1999). The challenges of globalization and the role of human resources. In Proceeding of the International conference on challenges of globalization, October, Bangkok. Retrieved October 24, 2014, from http://www.econ.tu.ac.th/iccg/papers/aminu.doc

Bird, B. (1995). Toward a theory of entrepreneurial competency. In J.A. Katz \& R.H. Brokhaus (Eds), Advances in entrepreneurship, firm emergence and growth (pp. 51-72). Greenwich, CT: JAI Press.

Bjornali, E.S. \& Støren, L.A. (2012). Examining competence factors that encourage innovative behaviour by European higher education graduate professionals. Journal of Small Business and Enterprise Development, 19(3), 402-423. http://dx.doi. org/10.1108/14626001211250135

Boselie, P. \& Paauwe, J. (2004). Human resource function competencies in European companies. Personnel Review, 34(5), 550-566, http://dx.doi. org/10.1108/00483480510612512

Bradley, S., Drapeau, M. \& DeStefano, J. (2012). The relationship between continuing education and perceived competence, professional support, and professional value among clinical psychologists. Journal of Continuing Education in the Health Professions, 32(1), 31-38, http://dx.doi.org/10.1002/chp. 21120

Brečko, D. (2006). Načrtovanje kariere kot dialog med organizacijo in posameznikom. Ljubljana: Planet GV.

Brockbank, W. (1997). HR's future on the way to a presence. Human Resource Management, 36(1), 65-69, http://dx.doi.org/10.1002/(SICI)1099-050X(199721)3 $6: 1<65::$ AID-HRM11>3.0.CO;2-D 
Budhwar, P.S. (2009). Human resource management in the Indian context. In P.S. Budhwar \& J. Bhatnagar (Eds.), The changing face of people management in India. London: Routledge.

Caldwell, R. (2003). The Changing roles of personnel managers: old ambiguities, new uncertainties. Journal of Management Studies, 40 (4), 983-1004, http://dx.doi. org/10.1111/1467-6486.00367

Chanda, A. \& Kabra, S. (2000). Human resource strategy-architecture for change. New Delhi, India: Response Books.

Devjak, T., Devjak, S. \& Polak, A. (2014). Dejavniki vpliva na izbiro pedagoškega poklica: motivi, pričakovanja in profesionalni razvoj. Didactica Slovenica Pedagoška Obzorja, 29(1), 3-18.

Diskienè, D. \& Marčinskas, A. (2007). Lithuanian managerial potential: state and perspectives. Vilnius, Lithuania: VU publishing office.

Druteikiene, G., Česyniene, R. \& Stankevičiene, A. (2013). Shift in functions and competences of human resources management professionals in the context of the labour market transformation. Transformations in business \& economics, 12(1), 73-90. Retrieved October 30, 2014, from http://www.vu.lt/leidyba/dokumentai/ zurnalai/EKONOMIKA/Ekonomika\%202013\%20 92\%203/123-140.pdf

Funčič Masič, T., Bakračevič Vukman, K. \& Schmidt, M. (2011). Razvitost nekaterih elementov kompetence učenje učenja pri dijakih srednjih poklicnih šol. Didactica Slovenica - Pedagoška Obzorja, 26(3), 91 - 114.

Garavan, T. N., \& McGuire, D. (2001). Competencies and workplace learning: some reflections on the rhetoric and the reality. Journal of Workplace Learning, 13(4), 144163, http://dx.doi.org/10.1108/13665620110391097

Gilmore, S. \& Williams, S. (2007). Conceptualising the ,personnel professional' ${ }^{6}$ a critical analysis of the chartered institute for personnel and development's professional qualification scheme. Personnel Review, 36(3), 398-414, http://dx.doi. org/10.1108/00483480710731347

Graham, M.E. \& Tarbell, L.M. (2006). The importance of the employee perspective in the competency development of human resource professionals. Human Resource Management, 45(3), 337-355, http://dx.doi. org/10.1002/hrm.20116

Harris, L., Doughty, D. \& Kirk, S. (2002): The devolution of $\mathrm{HR}$ responsibilities - perspectives from the UK's public sector. Journal of European Industrial Training, 26(5), 219-229, http://dx.doi. org/10.1108/03090590210424894

Johnson, C. D., \& King, J. (2002). Are we properly training future HR/IR practitioners? A review of the curricula. Human Resource Management Review, 12, 539554. Retrieved October 22, 2014, from http://www. latec.uff.br/mestrado/rh/Artigos/010.pdf
Kasiulis, J. (2005). Leadership Psichology, Kauans: Technologija.

Klieme, E. \& Leutner, D. (2006). Kompetenzmodelle zur erfassung indvidueller lernergebnisse und zur bilanzierung von bildungsprozessen. Beschreibung eines neu eingerichteten Scwerpunktprogramms bei der DFG, Zeitschrift fur Padagogik, 52, 876-903. Retrieved October 30, 2014 from http://www.forschungsnetzwerk. at/downloadpub/2006_ZfPaed_2006_Klieme_Leutner.pdf

Kohont, A. (2005). Kompetence slovenskih strokovnjakov za upravljanje človeških virov. In M. S. Pezdirc (Eds.), Kompetence v kadrovski praksi (pp. 103-123). Ljubljana: GV Izobraževanje.

Kohont, A. \& Brewster C. (2014). The roles and competencies of HR managers in Slovenian multinational companies. Baltic Journal of Management, 9(3), 294 -313, http://dx.doi.org/10.1108/BJM-07-2013-0112

Kotler, P., Keller, K.L., Brady, M., Goodman, M. \& Hansen, T. (2012). Marketing Management. Harlow: Pearson.

Kröl, M. (2003). The challenge of the age and competency structure in industry for innovation and human resource policy. Journal of European Industrial Training, 27(7), 355-371. http://dx.doi. org/10.1108/03090590310490025

Lambrechts, W., Mula, I., Ceulemans, K., Molderez, I. \& Gaeremynck, V. (2012). The integration of competences for sustainable development in higher education: an analysis by bachelor programs in management. Journal of Cleaner Production, 48, 65-73. Retrieved October 30, 2014 http://nera.cineca.it/vufind/Record/ ELV\%3AOXM34220.09596526.0048000C.11005750

Long, C.S. \& Ismail, W.K.W (2010). Readiness of Malaysian human resource professionals to be a strategic partner. Intangible Capital, 6(1), 26-50, http://dx.doi. org/10.3926/ic.2010.v6n1.p26-50

Long, C.S. \& Ismail, W.K.W. (2011). An analysis of the relationship between HR professionals' competencies and firm's performance in Malaysia. The International Journal of Human Resource Management, 22(5), 1054-1068, http://dx.doi.org/10.1080/09585192.2011. 556779

Lovelock, C.H. \& Wirtz, J. (2011). Services Marketing: People, Technology, Strategy. Boston: Prentice Hall.

Moore, D. \& Dainty, A. (2002). Competence, competency and competencies: performance assessment in organizations. Work Study, 51(6), 314-319, http://dx.doi. org/10.1108/00438020210441876

Nelson, R. \& Winter, S. (1982). An evolutionary theory of economic change, Cambridge, MA: Belknap Press.

O'Donoghue, J. \& Maguire, T. (2005). The individual learner, employability and the workplace. Journal of European Industrial Training, 29(6), 436 - 446, http:// dx.doi.org/10.1108/03090590510610236 
Pavlin, S. (2012). Slovensko visoko šolstvo s perspektive zaposljivosti diplomantov. Fakuleta za družbene vede. Retrieved October 17, 2014, from http://www.mfdps. si/Files/Karierni\%20center/Slovensko\%20VS\%20 s\%20perspektive\%20zaposljivosti\%20diplomantov. pdf

Rubin, N.J., Bebeau, M., Leigh, I.W., Lichtenberg, J.W., Nelson, P.D., Portnoy, S., Smith, I.L. \& Kaslow, N.J. (2007). The competency movement within psycology: an historical perspective. Professional Psychology: Research and Practice, 38(5), 452-462, http://dx.doi. org/10.1037/0735-7028.38.5.452

Rumelt, R.P. (1994). Foreword. In G. Hamel \& A. Heene (Eds.), Competence-based competition (pp. xv-xix). New York: Wiley.

Rychen, D.S. (2002). Key competencies for the knowledge society. A contribution from the OECD project definition and selection of competencies (DeSeCo). In: Education-Lifelong Learning and Knowledge Economy, 10-11 October. Stuttgart, Germany.

Sanchez, R. (2004). Understanding competence-based management Identifying and managing five modes of competence. Journal of Business Research, 57(5), 518532, http://dx.doi.org/10.1016/S0148-2963(02)003181

SHRM, (2010). What Senior Leaders Need to Know. Society for Human Resource Management. Retrieved October 19, 2014 from http://www.shrm.org/Research/SurveyFindings/Documents/10-0097\%20HR\%20 Leadership\%20Competencies\%20Exec.\%20Summary-FNL.pdf

Srimannarayana, M. (2013). Human resource competencies as perceived by executives. The Indian Journal of Industrial Relations, 49(2), 298-313. Retrieved October 30, 2013, from http://www.thefreelibrary.com/Human+resource+competencies+as+perceived+by+executives.-a0367966194

Storey, J. (1992). Developments in the Management of Human Resources. Oxford: Blackwell Publishing.

Taconis, R., Van der Plas, P. \& Van der Sanden, J. (2004). The development of professional competencies by educational assistants in school-based teacher education. European Journal of Teacher Education, 27(2), 215-240, http://dx.doi.org/10.1080/026197604200022 3051

Uhomoibhi, J. O. (2009). The Bologna Process, globalisation and engineering education developments. Multicultural Education \& Technology Journal, 3(4), 248255 http://dx.doi.org/10.1108/17504970911004255

Ullah, M. (2012). The emerging roles of HR professionals in driving organizational change. Journal of Knowledge Management, Economics and Information Technology, 2(3). Retrieved October 30, 2014 from http:// www.scientificpapers.org/wp-content/files/1290_Mamin_Ullah_The_Emerging_Roles_of_HR_Professio-
nals_in_Driving.pdf

Ulrich, D., Brockbank, W., Yeung, A.K. \& Lake, D.G. (1995). Human resource competencies: an empirical assessment. Human Resource Management Journal. 34(4), 473-495, http://dx.doi.org/10.1002/ hrm.3930340402

Ulrich, D. (1997). Human Resource Champions. Boston, MA: Harward Business School Press.

Ulrich, D., Brockbank, W., Johnson, D., Sandholtz, K., \& Younger, J. (2008). HR Competencies: Mastery at the Intersection of People and Business. Society for Human Resource Management: USA.

Venkata Ratnam, C.S, \& Srivastava, B.K. (1991). Personnel Management and Human Resources. Delhi: Tata McGraw-Hill.

Way, P. K. (2002). HR/IR professionals' educational needs and Master's program curricula. Human Resource Management Review, 12, 471 - 489, http://dx.doi. org/10.1016/S1053-4822(02)00073-6

Zlatkin-Troitschanskaia, O., Förster, M. \& Kuhn, C. (2013). Modeling and measuring university student's subject-specific competencies in the domain of business and economics - the Illev project. In S. Blömeke, O. Zlatkin-Troitschanskaia, C. Kuhn \& J. Fege (Eds.): Modelling and measuring competencies in higher education tasks and challenges (pp.159-170). Rotterdam: Sense Publishers.

Vesna Novak is an Assistant Professor at the University of Maribor, Faculty of Organizational Sciences, Slovenia. She is an author or co-author of various publications published in Slovenia and abroad. Her research interests are mainly focused on the current issues in human resources.

Anja Žnidaršič is an Assistant Professor of Quantitative Methods at the Faculty of Organizational Sciences, University of Maribor, Slovenia. Her main research interests are social network analysis, micro-enterprises and information-communication technology, students' performance in methodological courses and their competencies.

Polona Šprajc is an Assistant Professor a the University of Maribor, Faculty of Organizational Sciences, Slovenia. She is an author or co-author of various publications published in Slovenia and abroad. Her research interests are human resources and marketing. 